\section{Svak biografi}

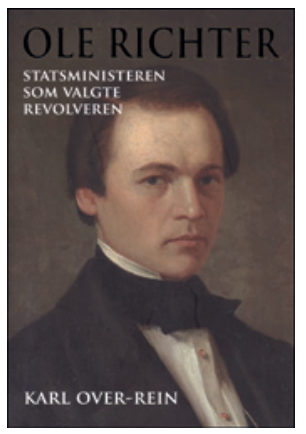

Karl Over-Rein

\section{Ole Richter}

Statsministeren som valgte revolveren. $347 \mathrm{~s}$, ill. Oslo: Forlaget Historie \& Kultur, 2011

Pris NOK 349

ISBN 978-82-92870-53-2

Ole Richter (1829-88) er en av de mest kjente og i stilling høytstående nordmenn som har tatt sitt eget liv. Han var 59 år og nettopp avsatt som leder (statsminister) av den faste norske statsrådsavdelingen i Stockholm. Tragedien vakte voldsom oppsikt sommeren 1888 og ble årsaken til en bitter strid i Venstre. Skyldspørsmålet ble diskutert i all offentlighet, og verken Johan Sverdrup (1816-92) eller Bjørnstjerne Bjørnson (1832-1910) kom godt fra det.

I 1957 ga historikeren Per Fuglum (1924-2008) ut første bind av sin grundige, forskningsbaserte biografi om Ole Richter. Det omhandler tiden frem til han forlot Stortinget i 1878 og ble generalkonsul i London. Sju år senere kom andre bind, et ikke mindre imponerende arbeid, som førte historien frem til Richters død. Biografisjangeren har utviklet seg mye siden den gang, ikke minst i synet på hva som er akseptabelt å formidle om privatlivet. Det er derfor forståelig at forlaget Historie \& Kultur har ønsket å gi ut en ny biografi om den sammensatte, interessante og ikke ubetydelige politikeren Ole Richter.

Forunderlig nok skriver imidlertid forfatteren Karl Over-Rein intet om eget perspektiv eller hva han ønsker å få frem som markerer en forskjell fra Fuglum, og som berettiger en ny bok. Har han hatt tilgang til nye opplysninger, kanskje brevsamlingen som ble funnet i Richters mausoleum? Svaret på det siste er nei. Over-Rein har faktisk benyttet langt færre kilder enn Fuglum, men han har, som forventet, et noe sterkere søkelys på selvmordet, og han har med noe mer stoff som belyser Richters personlighet og hans private affærer. Politikeren Richter får til gjengjeld vesentlig mindre plass enn hos Fuglum.

Det er vanskelig å skrive en god biografi. Over-Rein har skrevet flere romaner og slektshistoriske publikasjoner tidligere. Dette er hans debut som biograf. Da er det viktig å ha et forlag i ryggen som bidrar med så vel historiefaglig kvalitetssikring som språklig og kompositorisk kompetanse. Forlaget Historie \& Kultur har markert seg med en del riktig gode historiebaserte bøker, for eksempel Nina D. Kroglunds Hitlers norske hjelpere (2010). Det er synd å måtte si at Over-Reins bok oppleves mer som et foreløpig manus enn som en ferdig bok. Hele eller lange partier fra brev gjengis, delvis uten kommentarer. Et sted siteres nær fem sider i strekk med utdrag fra dagbøkene til vennen Ludvig Daae (1829-1893). Forfatteren evner heller ikke å behandle det historiske materialet på en betryggende måte. Hvor har forlagets historiefaglige korrektiv vært når slikt får passere: «For første gang var en regjering valgt av folket samlet.» (s. 228, om regjeringen Johan Sverdrup i Stortinget 1884). Eller denne, på samme side: «Parlamentarismen var endelig innført.» Professor Trond Nordby har senest $\mathrm{i}$ boken Grunnlov og styreform (2010) dokumentert at det skjedde gradvis og over flere tiår. Richter omtales som norsk-svensk ambassadør i London. Det ønsket han nok å bli, men var vitterlig generalkonsul.

Angivelsen av hvilke kilder som er benyttet, inngir heller ikke tillit. Fuglum er nevnt to steder i teksten, men hans tobindsverk er ikke med på listen over kilder. Det er heller ikke i denne sammenheng så sentrale utgivelser som Odd I. Skjæveslands bok om det norske ministerhotellet i Stockholm (2005) eller Edvard Hoems biografi om Bjørnson (de to første bindene).

\section{Frodig og lærd beretning}

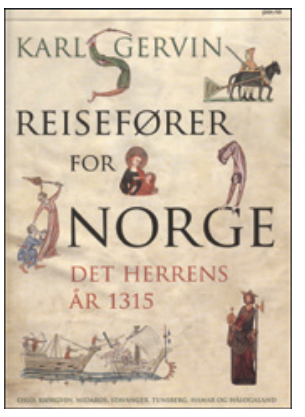

\section{Karl Gervin}

Reisefører for Norge det herrens år 1315

160 s, ill. Oslo: Pax Forlag, 2011. Pris NOK 288 ISBN 978-82-530-3433-1
Hva kunne tenkes å interessere en tilreisende i Norge - «det goldeste sted på jord» - i høymiddelalderen? Kanskje noe av det samme som også kan engasjere en nordmann 700 år senere, om enn på en litt annen måte - gjennom denne lille, vel illustrerte reiseføreren. Det som i 1315 må ha vært et særdeles eksotisk reisemål, ikke bare geografisk, blir i dag eksotisk pga. tidsspennet.

Konseptet, som er morsomt og vellykket gjennomført, er en beskrivelse av kongeriket Norge på 1300-tallet i form av en reisefører for en tenkt besøkende, det være seg en engelsk handelsmann eller en pavelig delegat fra Paris. Forfatteren er lærd teolog og idéhistoriker. Han målbærer en innlevelse i en annen epoke kombinert med solid historisk viten, med kilder helt fra antikken, og med lyssetting fra vår egen tid. Håndboken er full av så vel attraksjoner som advarsler. Det skildres riksstyre, lover, pengeverdier og priser, byggeskikk, matskikker, sedvaner, mentalitet, åndelig og kirkelig liv m.v.

I år 1315 har Oslo vært landets hovedstad i et år. Det foregående århundre hadde sett en enestående litterær blomstring i den norrøne verden. Svartedauden ligger ennå en generasjon frem i tid. Norgesveldet er stadig å regne med i Europa. Forfatteren nevner at Ludvig den hellige søkte om å få kong Håkon Håkonssønn med på korstog, som leder, men fikk til svar at «mitt folk er heftig, ubetenksomt og tåler ingen fornærmelser og kjenner ikke måtehold», og han frykter resultatet av møtet med «de overmodige franskmenn». En annen fransk kilde skildrer nordmennene som «robuste, aktive, velflidde og forbausende velorienterte».

Av de mange kuriøse opplysningene tilrådes, i skildringen av Bjørgvin, Nordens største by, å være på vakt overfor falske penger, $i$ tillegg til at man der finner «flere fordømmelige gjerninger enn noe annet sted på jord». Det advares generelt mot «putor», prostituerte, per definisjon kvinner som har ligget med en annen enn ektemannen hele tre ganger, ev. to ganger på en natt! Besøk i badstu koster ett øre, samme pris for årelating.

Man får vite at det er tre øre i bot for å skyte en pil mot noen uten å treffe; samme bot for å ha holdt bryllupsfesten gående mer enn to døgn. Om reisetider opplyses at det tar 19 dager fra Roma til Alpene, 26 derfra til Schleswig, så seks dager til Ålborg osv. Av reiseapotek nevnes loppeurt, høyst påkrevet, men vanskelig å finne i Norge. Som «vertinnegaver» er keramikk velsett, tilbake bør den reisende ta med kammer av hvalrosstann.

Et ledemotiv er jevnføringen av allehånde opplysninger og temaer med tilsvarende forhold i den øvrige, samtidige europeiske kristenheten. Også i så måte har boken en interessant aktualitet. Kolleger og andre trenger verken være middelalderromantikere eller medisinhistorikere for å bli fascinert av denne utgivelsen.

\section{Jon Geir Høyersten}

Sandviken sykehus Bergen 